\title{
The Economic Variables Associated with Financial Performance Interactions of French Football
}

\author{
Saad Ahmed Saad Shalaby*
}

French Football operates a unique model in managing and controlling French football clubs, and this helped these clubs to live in a healthy financial position with low debts compared with their Europeans neighbors. This model cannot success isolated from the environment economic variables for French clubs such as market size (population), individual income average and money spent on buying players, in addition to sport performance in local and international competitions. Therefore, the purpose of this current research is to examine interactions between economic variables related to the financial performance of the French clubs that occupied positions in Football Money League during the past ten years from 2000/2001 until 2009/2010: Olympique Lyon and Olympique Marseille, with employing method of analytical studies. The results showed a significant relationship between each of the economic variables and total financial revenues' streams for French clubs in different percentages, in addition to the absence of a significant relationship between attendance financial revenues for French clubs and some economic variables. The following parts will discuss both results and conclusions, in addition to exploring the interactions between all of the economic variables and financial performance and future research ideas.

\section{Introduction:}

French football considers a creature of the state where all organized sports fall under the responsibility of the state, who delegate leagues such as French Football Federation (FFF) to manage and operate football on its behalf. So we find that French clubs focus largely on directing all their resources and revenues toward football development, meantime they have limited ability on investing their available business opportunities.

French government interferes in football business because it includes all the economic and marketing and recreational factors for sports' values, where French football has became the first business field among different sports which the French society watch or practice,

*Assistant Professor, Sport Management Department, Faculty of Physical Education, Mansoura University, Egypt. in which its value surpassed (4) billion euros (De Balie, 2011).

Commercial revenues (ticket sales, sponsorship, Marketing television rights) had witnessed a great increase especially in broadcasting rights, which multiplied by $(600 \%)$ during the past (25) years, rising from (1.2) million euros in (1985) to (668) million euros in the current period (De Balie, 2011). However commercial revenues were not enough to cover permanent inflation in wage costs, and to achieve balance in the budgets clubs went to use commercial revenues when needed (De Balie, 2011).

In light of the global economic crisis, it was natural to effect in French clubs and show poor financial performance between Football Money League clubs', as a natural result of their overreliance on players' transfer to key markets in England and Spain (Barner, 2011). In which the economic crisis forced French clubs to reduce their purse depriving them from their largest 
revenue source. This crisis also led to a decline in matches' tickets sales (especially seasonal tickets) plus decline in sponsorship revenue (Down Media Group, 2011).

Despite these economic pressures, French clubs' debts were considered the lowest level among various European clubs in the top five leagues, where their total debt reached (15) milliard euros in (2010) and French clubs' share from that amount was (150) million euros, while the share of English club Manchester united alone was (900) million euros (De Balie, 2011). France operate a unique system in managing and controlling professional football clubs, in which this system aims to avoid clubs' bankruptcy in the middle of the season, which in turn leads to improper completeness for football championships, and consequently losing them. DNCG works as a committee responsible for monitoring French football and reviewing clubs' accounts and budgets, and if any club didn't respect the committee's rules, it may be punished with subjecting to a certain extent of control on buying and hiring new professional players plus the possibility of relegating the club to a lesser level, as what happened in (2003) when Monaco club was officially relegated due to poor financial management (Desbordes, 2007).

This system has helped French clubs to live in a healthy financial situation with relatively lesser debts comparing with their European neighbors, and the evidence on this is that Liguel global turnover in (2008) was positive for the third consecutive year (Jardin, 2009). Moreover, this type of control and monitoring considers one of the factors that led to a high level of competitive balance, and this is what distinguishes the high competitive balance for Ligue1 between major leagues.

French clubs have preserved a position within Football Money League in terms of financial performance over the past ten years $(2000 / 2001$ : 2009/2010). According to the unique success of the French model in managing professional football clubs and controlling their spending and revenues such as broadcasting rights secured by FFF, the French government indicated that in the second half of (2008) the UEFA presidency has announced their desire in applying the French control model in European football (Patel \& Szymanski, 2010).

\section{Literature Review:}

\section{1- Studies' results of and exports' opinions about financial revenues streams for Ligue1 clubs'}

Many researchers and specialists have examined and studied the economic characteristics and complexities associated with football as well as the changing nature of football industry and its revenue streams. Kearny (2011) suggested that football is a show business and all clubs must create, run and commercialize this show to optimize their revenues from all possible sources (such as: gate receipts, catering, corporate hospitality, sponsorship, TV rights, merchandising).

Szymanski (2010) indicates that financial revenues of football clubs depend on fixed financial revenues that are independent of performance in championships such as longterm sponsorship contracts, and there are number of revenues that are sensitive to performance (selling tickets \& merchandise, competitions' revenues as Champions League and domestic cup competitions).

Mason and Howarad (2008) indicated that clubs could increase their financial revenues streams productivity through two main axes: the first focuses on developing traditional revenue sources such as attendance \& broadcast rights sales to reach unprecedented levels, the second focuses on creating new revenue sources such as 
premium seats and partnership with sponsorship institutions and internet.

The results of Desbordes \& Hamelin (2010) analysis suggest balance absence in Ligue1 clubs' in terms of financial revenues contribution from previous mentioned sources in 2006/2007 season due to broadcasting rights' domination with the largest percentage in clubs' revenues with $(58 \%)$ of their total revenues, while sponsorship \& merchandising represent (26\%). These results also showed that French clubs total revenues from tickets are up to (139) million euros, and this approached the value of attendance revenue for the English club "Arsenal" with (134.6) million euros.

In agreement with results of Kern, Hass \& Dworak (2002) study in which they indicate that French clubs have (16\%) of their total financial revenues from attendance and this is considered the lowest level among top five European leagues.

Marino (2010) suggests that French clubs had recorded a higher growth rate in financial revenues, than top teams in Football Money League 2007/2008, where growth rates in both Lyon and Olympique Marseille came respectively $(8.3 \%)$ and $(9.1 \%)$, while Real Madrid and Manchester United came respectively (5\%) and (4.7\%) due to slowing growth rates in TV broadcasting rights at big clubs in the following years (Houliham et al, 2009).

Houliham et al (2010) mentioned that due to the tough economic environment, Olympique Lyon suffered from a decline in commercial revenues by (17\%) in season 2008/2009 from previous season 2007/2008, plus that current stadium capacity restricted club's ability to achieve significant revenues from this source. Meanwhile Olympique Marseille generated (24.9) million euros in attendance revenues which considered one of the most lower values between Football Money League clubs', they also indicated that extending shirt sponsorship deal with Direct Energy companies who reportedly pay (5) million euros per year contributed to the increase in club's commercial revenue by $(26 \%)$.

Battle et al (2011) in season 2009/2010 show that broadcasting revenues represent a large part from French clubs' financial revenues (which occupied positions between Football Money League club's), where it represents (54\%) for Olympique Lyon and (50\%) for Olympique Marseille as a natural result of improved sport performance in national and UEFA championships. Commercial revenues comes in the second place by (25\%) for Olympique Lyon and $(32 \%)$ for Olympique Marseille, meanwhile attendance revenues are still a major challenge for French clubs as a result of French stadiums' low quality, which led both clubs to develop plans including moving to new stadiums to be able to develop their financial revenues from that source.

The results of Andreff (2007) agrees with previous conclusions which say that prosperity in French clubs' financial revenues came as a natural result of the increase in broadcasting rights' revenues, and also confirms that broadcasting rights value must continue to grow to help in preserving financial turnover rate within $(60 \%)$ and this agree with Zegband et al (2011) who mentioned that football broadcasting revenues' likely translated to a growth slowdown from (8\%) to $(4 \%)$ per year.

\section{2- Studies' results of and exports' opinions about economic characteristics \& complexities related to financial revenues streams for Ligue1 clubs'}

The results of the Barner (2011) and Down Media Group (2011) studies' show that the global economic crisis led to French clubs showing poor financial performance between 
Football Money League clubs' in the big five European leagues as a natural result of their over-reliance on players' transfer to key markets in England and Spain. In which the economic crisis forced them to reduce their purse and deprive French clubs from their largest revenue source. This crisis also led to a decline in matches' tickets sales especially seasonal tickets, plus decline in sponsorship revenues.

The results of Kearney (2011) suggests that limited economic environment of the club make the key revenue source is buying players, because this strategy generates profits such as: Auxerre club have been consistently profitable and often successful on the pitch, despite being situated in a city of just 40000 inhabitants.

The study of Jardin (2009) shows that both variables: population and points' number in the championship didn't have any impact on the revenues efficiency within 2004: 2007, meanwhile total inflation in wages had jumped to $(47 \%)$ between 2004: 2007 , and this affected on turnover. The results also indicate that external environmental factors (that falls beyond the control of the manager) affect on club's efficiency level.

Szymanski (2010) study suggests that revenues depend partly on the prevailing conditions in the macroeconomic that influence on expenditure and income patterns, in addition to the effect of individual income average on attendance demand on football events and competitions, as well as his share of GDP. The correlation coefficient between both attendance revenues and change percentage in Liguel's attendance reached $(57 \%)$.
Football business has become a very huge rapidly growing field all over the world, creating a continuous need for development, creativity and innovation based on scientific bases, where there are many complexities and special characteristics associated with football as well as the changing nature of football industry and its revenues' streams (Soderman et al, 2010). Which requires understanding the key economic variables associated with football business' complexities and examining their interactions deeply and figuring their significance that consistent with football business characteristics (Soderman et al, 2010)?

The success of the French model in managing and controlling French clubs' financial performance can't be achieved isolated from the environment economic variables such as: market size, individual income average, money spent on buying players in addition to sport performance represented in number of Championships in local and international sport competitions.

Therefore, the purpose of this current research is to understand interactions between economic variables related to French clubs' financial performance (who occupied positions between Football Money League in the last ten years) under this unique system of management and control for professional French football clubs. The system that Europe is seeking to apply in the beginning of (2012), to contribute in helping marketing and financial decision makers at football clubs on understanding the nature of the relationship between the economic variables and clubs' financial performance and taking financial decisions in the light of realizing the nature of this relationship.

\section{Research Questions}

\section{Problem Statement:}


Here are the key questions that face this research:

1. What is the relationship's direction between market size (population) and the financial revenues' variables for French clubs?

2. What is the relationship's direction between individual income average and the financial revenues' variables for French clubs?

3. What is the relationship's direction between money spent on buying players and the financial revenues' variables for French clubs?

4. What is the relationship's direction between sport performance in completions' and the financial revenues' variables for French clubs?

\section{Research Tools:}

This research relied on data from Football Money League publications for top 20 clubs in top five European leagues during seasons 2000/2001: 2009/2010, which included data for two French clubs (that held positions in the ranking over the past ten years), Olympique Lyon and Olympic Marseille. These data included total revenues and the main financial variables (attendance revenue- commercial revenues- broadcasting revenues) in addition to data of population and individual income average from World Fact Book since 2001: 2010.

The research also relied on statistics from European football-statistics website to identify the ranking of the French clubs in national and European competitions.

\section{Research Methodology:}

This research has employed analytical studies method (case studies) and this is a worthwhile research approach, where this approach relies on collecting data about French clubs' financial revenues through Football Money League publications. The researcher selection for this method is justified because the financial performance of French clubs considers an independent case with highly private nature from space and time. Beside that, this approach provides a specific analysis of French clubs' financial performance and their relationship with economic variables. This helps marketing and financial decision makers to understand the nature of the relationship between economic variables and clubs' financial performance.

\section{Research Population:}

The research population included French football clubs which held a position in Football Money League during the past ten years (2000/2001: 2009/2010), where the sample was selected intentionally represented in Olympique Lyon and Olympique Marseille who have achieved the highest financial revenues between different French football clubs over the past decade as well as working within the French system of financial managing and controlling (DNCG). 
Research Results:

First question which relates to the relationship's nature between market size (population) and French Clubs' financial revenues variables, where figure (1) shows that market size explains (69.1\%) of changes occurred in the French Clubs' total financial revenues during 2000/2001 to 2009/2010, it also

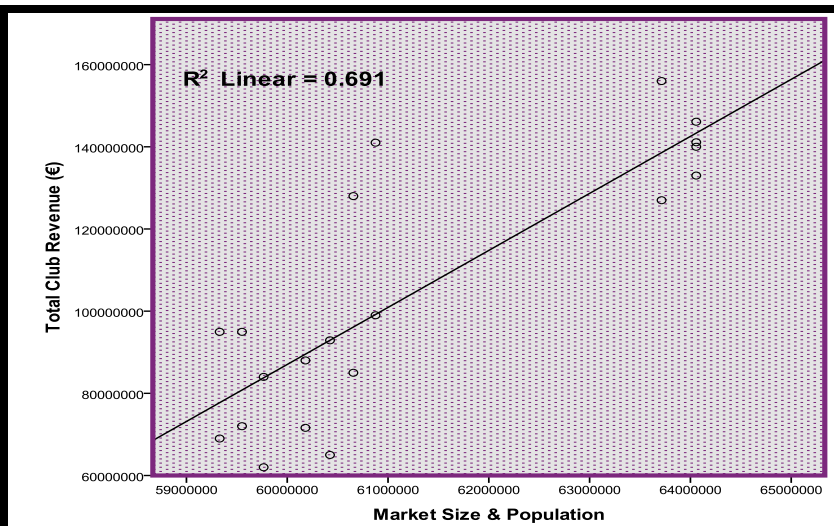

Total Revenues with Market Size

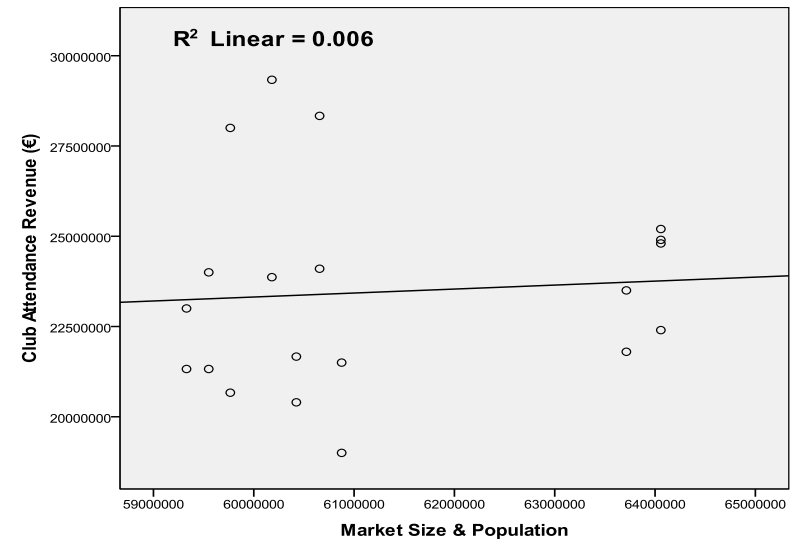

Attendance Revenues with Market Size shows that market size explains (64.6\%) of French Clubs' broadcasting financial revenues, on the contrary we find that attendance revenues aren't affected by market size. This means that market size explains (69.1\%) of changing in French Clubs' total financial revenues, and explains $(60.2 \%)$ of changing in French Clubs' commercial financial revenues.

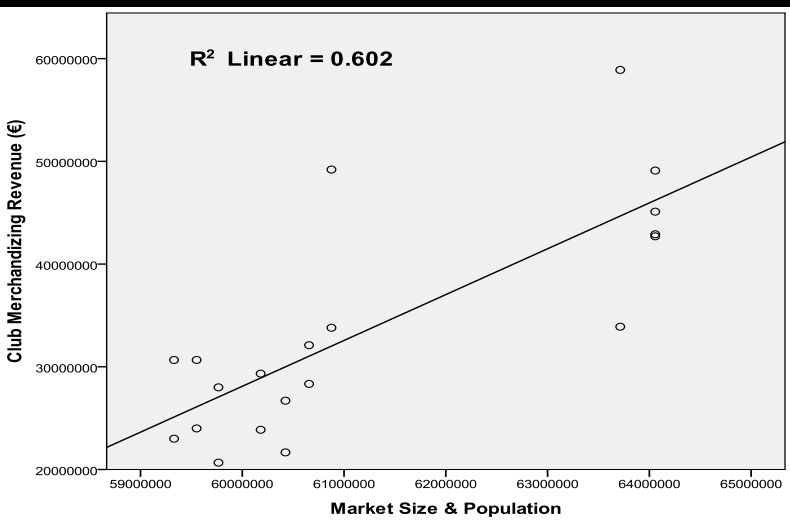

Commercial Revenues with Market Size

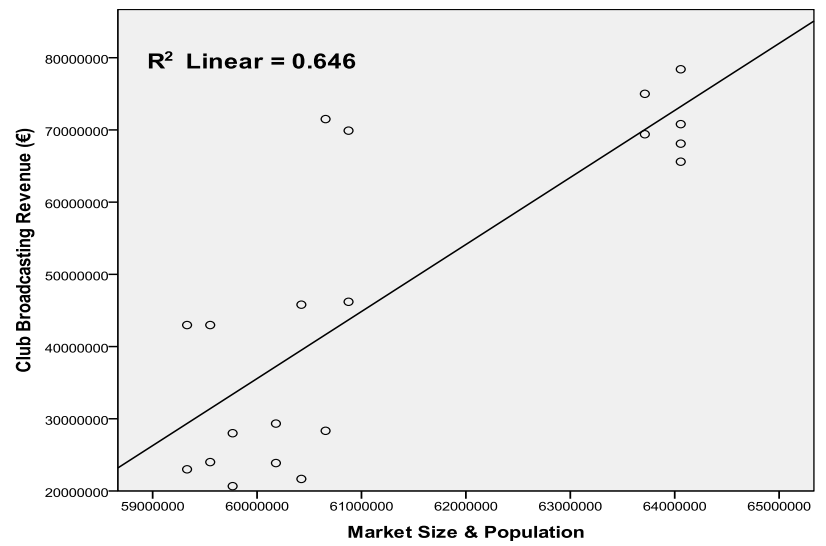

Broadcasting Revenues with Market Size

Figure (1) the impact of market size on different revenues variables for football French clubs 
Second question which seeks to illustrate the relationship between individual income average and French Clubs' financial revenues variables, where figure (2) shows that individual income average explains $(65.8 \%)$ of changes occurred in total financial revenues for French clubs during 2000/2001: 2009/2010, and explains $(64.3 \%)$ of changing in French clubs' broadcasting revenues, on the contrary we find that individual income average does not contribute in explaining French clubs' attendance revenues, in addition that individual income average explains (53.2\%) from changes in French clubs' commercial revenues.

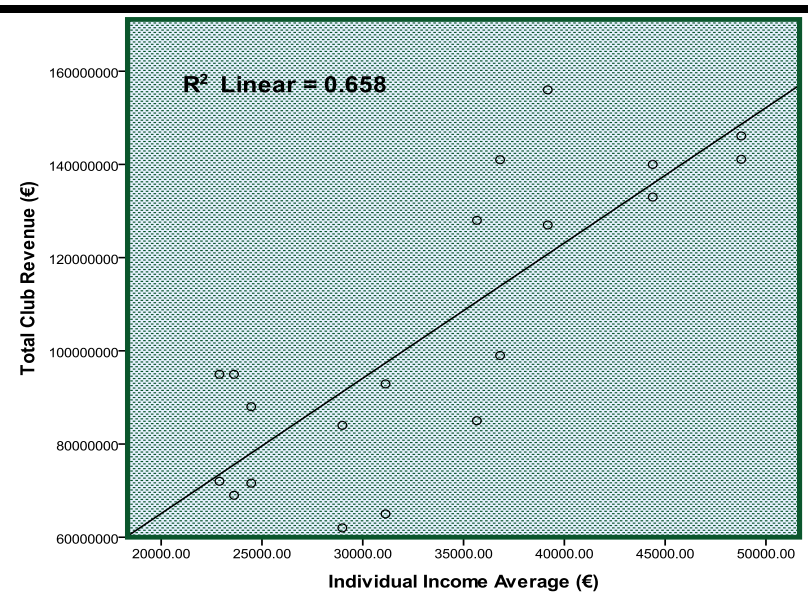

Total Revenues with individual income average

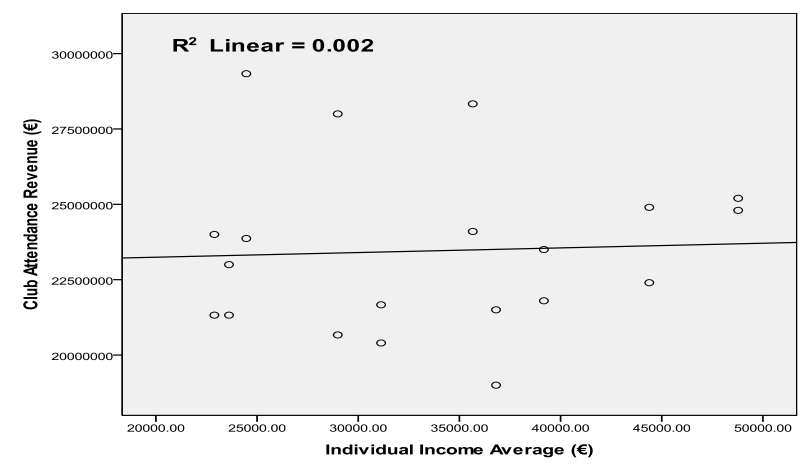

Attendance Revenues with individual income average

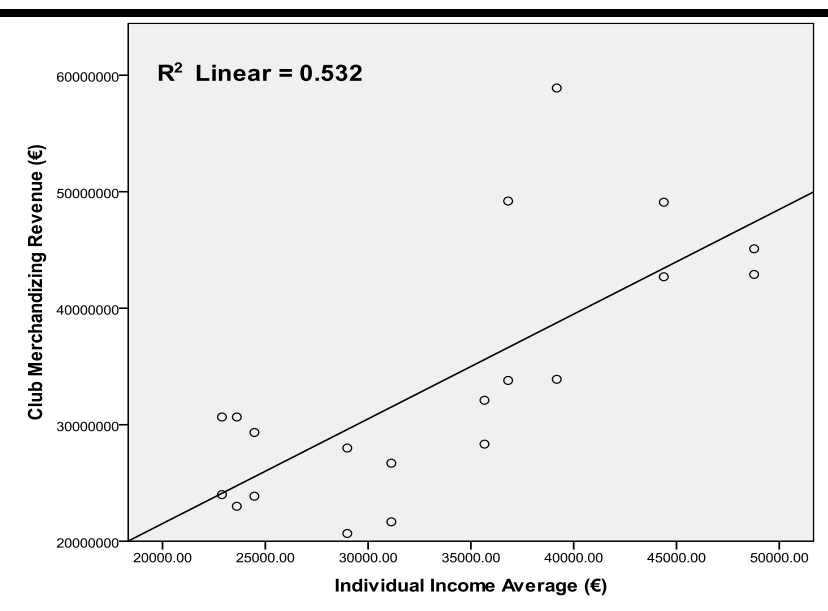

Commercial Revenues with individual income average

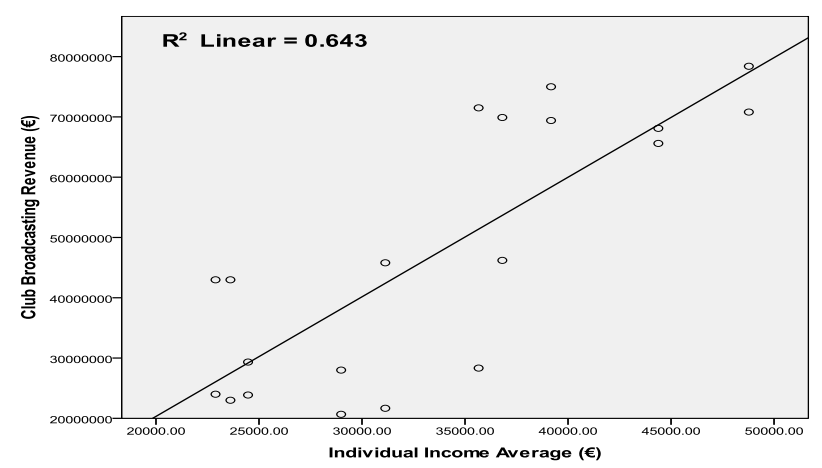

Broadcasting Revenues with individual income average

Figure (2) the impact of individual income average on different revenues' variables for football French clubs 
Third Question which sought to illustrate the relationship between the money spent on buying players and French Clubs financial revenues' variables, where figure (3) shows the possibility of explaining (49.5\%) of changes occurred in French clubs' total financial revenues through spending money on buying players, also shows the presence of a strong relationship between French clubs' broadcasting revenues and money spent on buying players which in turn explain (51.4\%) from broadcasting revenues, plus providing explanation for $(35.1 \%)$ of commercial revenues through money spent on buying players, the figure also shows the weakness impact for money spent on buying players and attendance revenues.

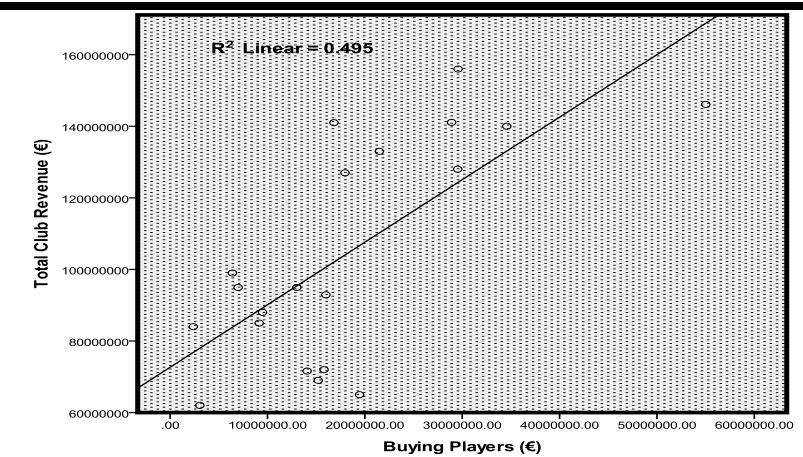

Total Revenues with buying players

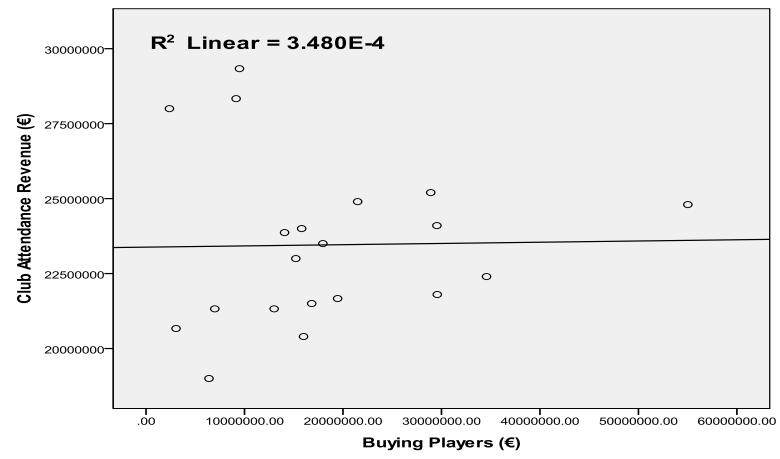

Attendance Revenues with buying players

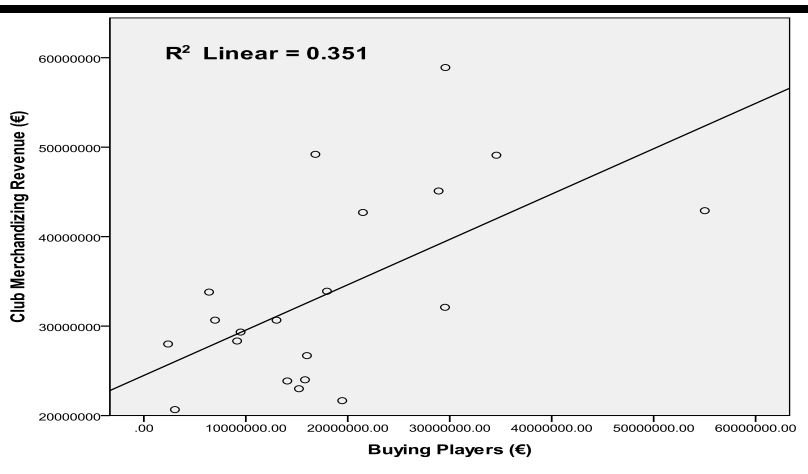

Commercial Revenues with buying players

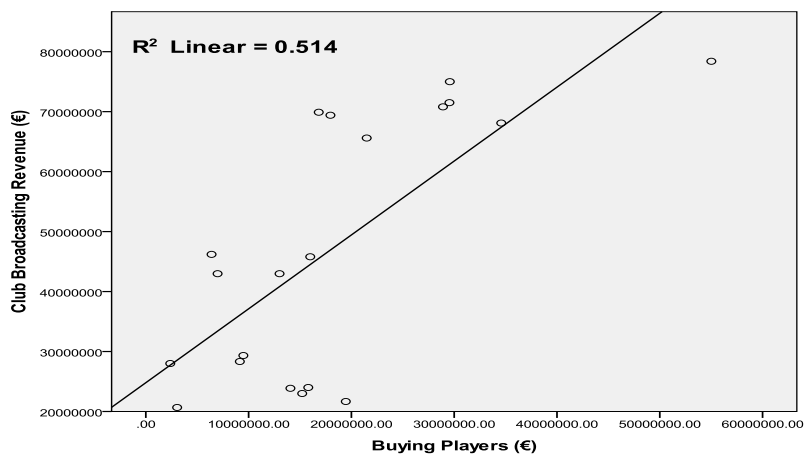

Broadcasting Revenues with buying players

Figure (3) The impact of money spent on buying players on different revenues' variables for football French clubs 
Fourth question which relates to contributing in a very limited percentage in relationship's nature between performance in explaining the change occurred in French clubs' competitions and French Clubs' financial total financial revenues with $(27.2 \%)$, also the revenues' variables, where Figure (4) shows commercial revenues were influenced by that performance in competitions has a performance in competition with a similar significant effect in explaining the main sources degree in which it explain $(22.4 \%)$ of changing of revenues (broadcasting revenues- commercial in French clubs' financial revenues from this revenues- attendance revenues) plus field.

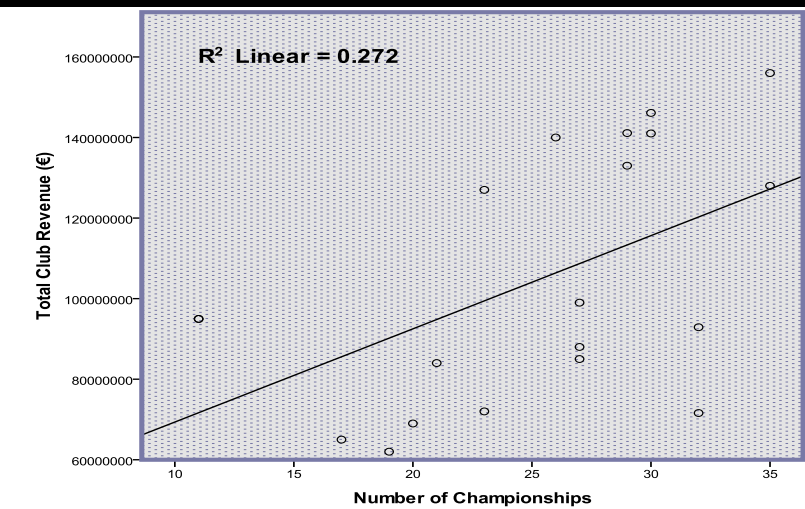

Total Revenues with Number of championships

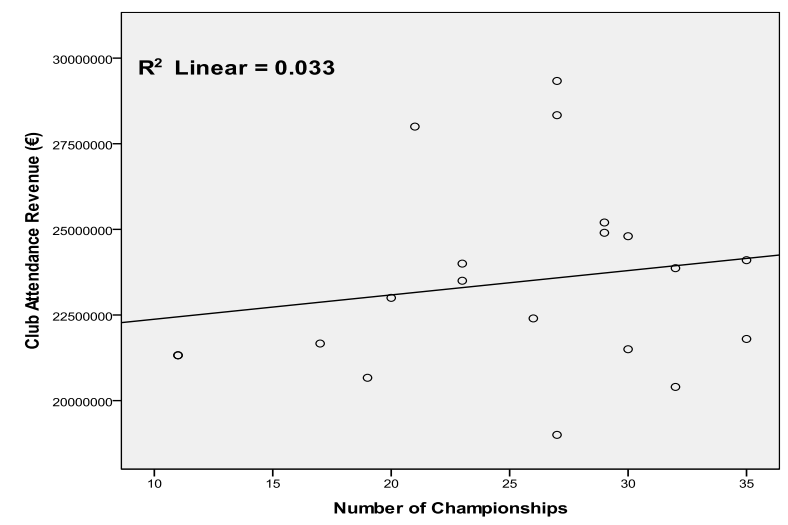

Attendance Revenues with Number of championships

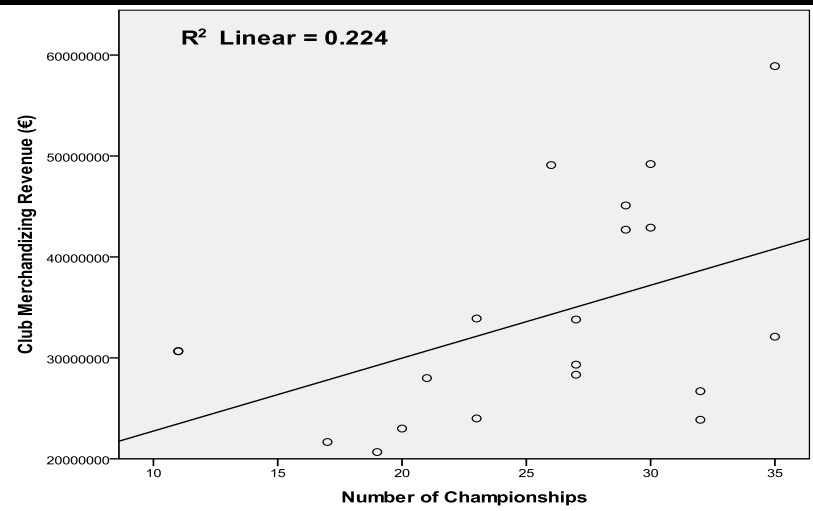

Commercial Revenues with Number of championships

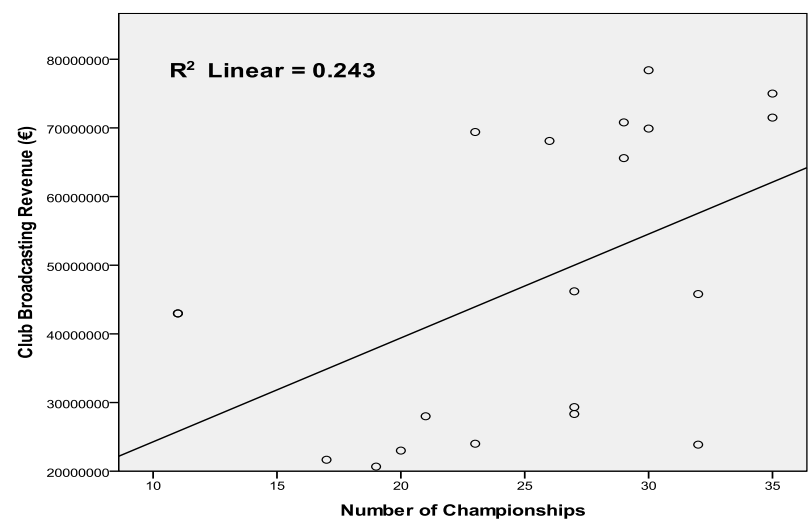

Broadcasting Revenues with Number of championships

Figure (4) The impact of performance in competition on different revenues' variables for football French clubs 


\section{Discussion:}

This study has sought to understand both interactions and relationships between economic variables and French clubs' financial performance that held a position in Football Money League over the past ten years during $2000 / 2001$ to 2009/2010. Research results showed that macro-economic environment variables that focuses in general on great economic interactions (population- individual income average) as well as microeconomic environment variables that focuses on managers' decisions (determining money values spent on the buying players), both had a great interaction impact in explaining French clubs' total financial revenues as well as financial revenues' sources from broadcast revenues and commercial revenues.

Research results' showed that the economic variables (population- individual income average- money spent on buying players) did not contribute in translating French clubs' attendance revenues. This is due to attendance revenues affected by many other variables that were not studied here, such as stadiums' quality that lead to high attendance revenues. This agree with Wakefield (2007) results' who suggests that stadiums' quality explain (42\%) of attendance revenues, in addition to that population variable may play a negative impact on attendance rates and then on attendance revenues. This is assured through looking at French clubs' map, we find the presence of (14) Clubs in south of France, and this increases the competition these clubs and each other on local audiance beside the competition that these clubs face from leisure activities' providers. This is consistent with Wakefield (2007) in which he says that competition in big cities with high population is very hard between sports and other leisure activities.
The results showed that economic variables are the most influential and interactive in explaining French clubs' broadcasting financial revenues bigger than other financial sources (commercial revenues- attendance revenues that agree with previous reference studies. Moreover, French clubs still miss balance between their financial revenues' sources, which make them vulnerable to violent financial shocks, in the case of broadcast revenues' slower growth as been predicted in Rothenbucher et al (2010). On the other hand, we find that strong correlation between performance in competitions and broadcast revenues may be exposed to many difficulties, especially in European competitions due to the French clubs' inability on buying best players that reduced their ability to reach advanced positions in the competition and caused a declination in broadcasting revenues.

The results also showed that money spent by French clubs considered very small when in comparison with their neighbors in big European leagues. Which leads to the fact that top players may choose to improve their financial earnings through playing with ItalianEnglish- German clubs instead of their French clubs and that became easy after Bosman rule in addition to unique French football control and management system (DNCG). John Beach's (2010) results suggest that most highest players' buying deals in 2008 were at Spanish- ItalianEnglish clubs while French clubs share did not exceed $(2 \%)$ from these deals.

This led to that variable of money spent on buying players did not contribute in translating French clubs' attendance revenues, due to the fact that the money spent by French clubs on buying players do not enable them to attract distinguish players who give fans confidence and link to the team, which in turn reflected on attendance revenues. This is consistent with Wakefield (2007) results' in that money spent on players' salaries considers the second largest 
factor influencing on attendance, and in so increases attendance revenues, because fans are often associated with one of the teams as a result for presence of strong talented players.

\section{Conclusions:}

- This study has its value in the field of developing financial revenues (broadcasting revenues- commercial revenues- attendance revenues) especially for the French football clubs which occupied a position in Football Money League in terms of financial performance, because it reveal the role of the economic variables in explaining the financial performance of these clubs, it also reveal of an opportunity to target a group of other economic variables that can interact in developing and improving French clubs' financial performance that can be considered a tool for helping marketing managers to take into consideration when planning their clubs' businesses.

- In future we have to expand in further researches on the interactions between economic environment's variables which clubs are operated in and their financial revenues especially in Arabian clubs' environments that do not have such studies due to the lack in databases which show the financial performance of these clubs across different periods of time.

- This study results' have revealed that broadcasting financial revenues consider the cornerstone of interaction with economic environment variables plus balance absence between key revenue sources as well as balance in the interaction between economic variables and key revenue sources for French Clubs (broadcasting revenue commercial revenues - attendance revenue).

\section{References:}

1. Andreff, W. (2007). French Football: A Financial Crisis Rooted in Weak Governance. Journal of sports economics. Sage Publications.

2. Battle, R., Bull, A., Hawkins, M., Hearne, S., Parkes, R \& and Thorpe, A. (2011). The untouchables: Football Money League. Sports Business Group at Deloitte. England

3. Beech, J. (2010). Finance in Football Industry. In: Hamil, S. \& S.Chadwick: Managing Football. An International Perspective. Butterworth- Heinemann England, 137.

4. Desbordes, M. (2007). The Role of Management Control in French Football's Regulation- A Unique Model That Can Be Exported?. In: Desbordes, M. Marketing and Football. An International Perspective. Butterworth- Heinemann, England, 92.

5. Desbordes, M., \& Hamelin, A. (2010). France. In: Hamil, S. \& S.Chadwick: Managing Football. An International Perspective. Butterworth- Heinemann England,304 305, 308, 311-312.

6. Dobson, S., \& Goddard, J. (2011). Football around the world: France, Germany, Brazil, Japan and China. Cambridge U.S.A 384,385.

7. Houlihan, A., Parkes, R., Bull, A., Hawkins, M., Hearne, S., \& Schmick, C. (2010). Spanish Masters: Football Money League. Sports Business Group at Deloitte. England

8. Houlihan, A., Parkes, R., Hawkins, M., Hearne, S., Ashton,A., \& Schmick, C. (2009). Lost in Translation: Football Money League. Sports Business Group at Deloitte. England

9. http://economicsnewspaper.com/economics/ change-or-die-what-future-for-football14565.html. De Balie.

10. http://www.cia.gov/library/worldfactbook.. 
11. http://www.dawn.com/2011/03/09/financialclimate-makes-french-clubs-nervous.html. Dawn Media Group.

12. http://www.european-footballstatistics.co.uk..

13. http://www.goal.com/engb/news/3274/ligue-1/2011/04/23/why-lillecan-hope-to-keep- eden-hazard-and-lyonwill-struggle-to. Robin Barner.

14. Jardin, M. (2009). Efficiency of French football clubs and its dynamics. MPRA. Muenchen.

15. Kearney, A, T. (2011). Winning strategies for football in Europe and around the Globe. A.T.Kearny Inc. U.S.A

16. Marino, D. (2010). Governance and Sporting Success of Top 20 Football Clubs After Economic Crisis. In: Butenko, S., Lafuente, J., \& Pardalos. P. Optimal Strategies in Sports Economics and Management. Springer, London, 87.

17. Mason, D., \& Howard, D. (2008). New Revenues Streams in Professional Sports. In: Humphreys, B., \& Howard, D. The Business of Sport (Volume 1). Praeger, London, 125, 126

18. Patel, S., \& Szymanski, S. (2010). Leagues and Competitions. In: Hamil, S. \& S.Chadwick: Managing Football. An
International Perspective. ButterworthHeinemann England, 186.

19. Rothenbucher, J., Mesnard, X., Rossi, L., Lucero, M., \& Hembert, E. (2010). E U Football Sustainability Study: Is European football too popular to fail?. A.T.Kearny Inc. U.S.A.

20. Soderman, S., Dolles, H., \& Dum, T. (2010). International and Global Development. In: Hamil, S. \& S.Chadwick: Managing Football. An International Perspective. Butterworth- Heinemann England, 86, 87, 92.

21. Syzmanski, S. (2010). Commercial Football and The Economic Cycle. In: Butenko, S., Lafuente, J., \& Pardalos. P. Optimal Strategies in Sports Economics and Management. Springer, London, 188, 193.

22. Wakefield, K. (2007). Team Sports Marketing. Butterworth- Heinemann,China, $45,85$.

23. Zygband, P., Collignon, H., Sultan, N., Santander, C., \& Valensi, U. (2011). The Sports Market: Major trends \& challenges in an industry full of passion.
A.T.Kearny
Inc.
U.S.A 
